CLINICAL STUDY

\title{
Incidence and prevalence of nutritional and hereditary rickets in southern Denmark
}

\author{
Signe Sparre Beck-Nielsen, Bendt Brock-Jacobsen ${ }^{1}$, Jeppe Gram ${ }^{2}$, Kim Brixen ${ }^{3}$ and Tina Kold Jensen ${ }^{4}$ \\ Department of Pediatrics, Hospital of Southwest Denmark, Finsensgade 35, DK-6700 Esbjerg, Denmark, ${ }^{1}$ Department of Pediatrics, Odense University \\ Hospital, 5000 Odense, Denmark, ${ }^{2}$ Department of Endocrinology, Hospital of Southwest Denmark, 6700 Esbjerg, Denmark, ${ }^{3}$ Department of \\ Endocrinology, Odense University Hospital, University of Southern Denmark, 5000 Odense, Denmark and ${ }^{4}$ Department of Environmental Medicine, \\ Institute of Public Health, University of Southern Denmark, 5000 Odense, Denmark
}

(Correspondence should be addressed to S S Beck-Nielsen; Email: sbeck-nielsen@health.sdu.dk)

\begin{abstract}
Objective: To estimate the incidence of nutritional rickets and the incidence and prevalence of hereditary rickets.

Design: Population-based retrospective cohort study based on a review of medical records.

Methods: Patients aged 0-14.9 years referred to or discharged from hospitals in southern Denmark from 1985 to 2005 with a diagnosis of rickets were identified by register search, and their medical records were retrieved. Patients fulfilling the diagnostic criteria of primary rickets were included. Results: We identified 112 patients with nutritional rickets of whom 74\% were immigrants. From 1995 to 2005, the average incidence of nutritional rickets in children aged 0-14.9 and 0-2.9 years was 2.9 and 5.8 per 100000 per year respectively. Among immigrant children born in Denmark, the average incidence was 60 (0-14.9 years) per 100000 per year. Ethnic Danish children were only diagnosed in early childhood and the average incidence in the age group 0-2.9 years declined from 5.0 to 2.0 per 100000 per year during 1985-1994 to 1995-2005. Sixteen cases of hereditary rickets were diagnosed during the study period giving an average incidence of 4.3 per 100000 (0-0.9 years) per year. The prevalence of hypophosphatemic rickets and vitamin D-dependent rickets type 1 was 4.8 and 0.4 per 100000 (0-14.9 years) respectively.

Conclusions: Nutritional rickets is rare in southern Denmark and largely restricted to immigrants, but the incidence among ethnic Danish children was unexpectedly high. Hereditary rickets is the most common cause of rickets in ethnic Danish children, but nutritional rickets is most frequent among all young children.
\end{abstract}

European Journal of Endocrinology 160 491-497

\section{Introduction}

Rickets is characterized by defect mineralization of bones and growth zones. It is primarily caused by nutritional vitamin $\mathrm{D}$ or calcium deficiency; however, in rare cases, rickets is hereditary caused by inborn genetic diseases (1).

Although the pathophysiology of nutritional rickets and preventive measures are well recognized, the disease is not eradicated in industrialized countries (2). In a study conducted in Copenhagen between 1990 and 1999, only 40 cases of rickets were found, all among immigrant children (3). Since no cases of nutritional rickets were diagnosed among ethnic Danish children, the disease was confined to immigrant children only. This is unexpected as children of Danish origin were treated in hospitals in our region of southern Denmark during that time period. The incidence of nutritional rickets has recently been estimated in studies from Canada (4) and the UK (5), but the incidence in Scandinavia has not been reported. One paper has conservatively estimated the incidence of hypophosphatemic rickets to be 1:20-25000 (6), but we suspect that this reported incidence may be a prevalence.

By the use of Danish registers and medical records from hospitals in the region of southern Denmark, we therefore attempted to estimate the incidence of nutritional rickets and the incidence and prevalence of hereditary rickets. From this cohort of children with rickets, we have also reported clinical and biochemical characteristics and risk factors (7).

\section{Patients and methods}

\section{Register study}

In Denmark, all citizens have a unique personal identification number (CPR number) making it possible to link personal information from different registers and 
hospital records, and to link children to parents. The data on ethnicity of the parents and place of birth of the children were collected from The Central Office of Civil Registration and linked to the child by the use of the CPR number.

Medical records from patients referred to or discharged from hospitals in southern Denmark from 1985 to 2005 with diagnosis codes referring to rickets were identified: (World Health Organization's International Classification of Diseases, Revision 8 and 10); 265, 265.09, 265.19, 265.99, 273.40, E55, E55.0, E55.9, E64.3, or E83.3 from hospital registers and/or in the Danish National Patient Registry (DNPR). DNPR comprises the data on all hospitalized patients from 1977, and in addition all outpatient contacts from 1995. The incidence of nutritional rickets was therefore estimated before and after 1995. Medical records from southern Jutland County (comprising 19\% of the region of southern Denmark) were unavailable from 1985 to 1991 as electronic registration was only implemented thereafter. The population in that county during this period was therefore omitted from the calculation of incidence. Medical records from patients identified in the different registers were retrieved by the use of their CPR number and reviewed by the first author (SBN).

Patients aged 15 years or more at the time of first diagnosis or with secondary rickets were excluded. To verify the diagnosis of nutritional and hereditary rickets, and to exclude secondary rickets, the entire medical record(s) were carefully reviewed including information on biochemical and radiological investigations. Thus, patients with rickets due to renal insufficiency, distal or proximal renal tubular acidosis, liver/bile duct disease, malabsorption, rickets secondary to syndromes, or medically induced rickets were excluded. Patients with suspected nutritional rickets and with serum 25-hydroxyvitamin D $(25(\mathrm{OH}) \mathrm{D}) \geq 50 \mathrm{nmol} / \mathrm{l}$ were also excluded.

The diagnosis was validated upon predefined diagnostic criteria; cases fulfilling both biochemical inclusion criteria and clinical signs/symptoms or radiological signs of rickets were included. Vitamin D insufficiency is defined as serum $25(\mathrm{OH}) \mathrm{D}<50 \mathrm{nmol} / \mathrm{l}$, vitamin D deficiency as serum 25(OH)D 12.5$25 \mathrm{nmol} / \mathrm{l}$ and severe vitamin D deficiency as serum $25(\mathrm{OH}) \mathrm{D}<12.5 \mathrm{nmol} / \mathrm{l}(8)$. Biochemical inclusion criteria of nutritional rickets were severe vitamin D deficiency or vitamin D deficiency and at least one of the following: raised plasma alkaline phosphatase (ALP), raised serum parathyroid hormone (PTH), or low serum calcium (Ca) (9). When no serum 25(OH)D measurements were available, at least one of the following criteria were fulfilled: raised plasma ALP, raised serum PTH, or low serum Ca. In addition, in patients with nutritional rickets, the rickets had to heal upon treatment with vitamin D. Biochemical inclusion criteria of hypophosphatemic rickets were defined as: raised plasma ALP, low plasma phosphate $\left(\mathrm{PO}_{4}\right)$, normal serum PTH, and normal serum Ca (10). Biochemical inclusion criteria of vitamin D-dependent rickets type 1 (VDDR type 1 ) were defined as: raised plasma ALP, raised serum PTH, low to normal serum Ca, low plasma $\mathrm{PO}_{4}$, serum 1,25-dihydroxyvitamin D $\left(1,25(\mathrm{OH})_{2} \mathrm{D}\right)<15 \mathrm{pmol} / \mathrm{l}$, and serum $25(\mathrm{OH}) \mathrm{D}$ within the reference range of $50-178 \mathrm{nmol} / \mathrm{l}$ (11). Furthermore, the diagnosis of VDDR type 1 and hypophosphatemic rickets required the condition to be refractory to treatment with vitamin D only. Among infants and young children, the diagnostic clinical signs/symptoms were at least one of the following: craniotabes, rachitic rosary, Harrison groove, enlargement of the wrists, knees or ankles, bowing of weight bearing extremities or hypocalcemic seizures $(12,13)$. In adolescence, clinical signs/symptoms were at least one of the following: enlargement of the wrists, knees or ankles, bowing of legs, muscle weakness, pain of the lower limbs or in the back or hypocalcemic seizures (12). Radiological signs were widening of the growth plates with irregularity and cupping of their metaphyseal borders (9).

The study was approved by the Ethics Committee of southern Denmark (M-2678-05) and by the Danish Data Protection Agency.

\section{Questionnaire survey}

In order to identify patients with rickets treated exclusively in the primary health care sector, questionnaires were sent to all general practioners (GPs) and pediatricians working in primary care in the study region. They were asked to assess whether they had treated and/or referred patients to hospital evaluation in suspicion of rickets in 2005, and if so they were contacted by telephone for verification.

\section{Statistical analysis}

The incidence of nutritional rickets was calculated in two study periods (1985-1994 and 1995-2005), before and after the registration of outpatients in the DNPR. The average yearly incidence during the two study periods was calculated as the mean of the total number of children diagnosed with nutritional rickets for the first time during the study periods divided by the mean of the reported yearly total number of children in that age group living in southern Denmark during the study period, assuming each child to contribute 1 year of risk time. Information about the total number of children living in the area on the 1st of January each year was obtained from Statistics Denmark (http:// www.statistikbanken.dk/). The incidence of nutritional rickets among immigrants was only calculated among children born in Denmark. Immigrant families, who might only be in Denmark for a short period of time while their application for asylum is considered, are not recorded in the population registers. Consequently, the 
data on these families are not included in this study. The incidence among children born in Denmark of immigrant parents of different ethnic origin was calculated as for Danish children but divided by the population of children of that ethnic group during the study period. The data on the ethnicities of the parents and place of birth were collected from The Central Office of Civil Registration. As only ten immigrant children born in Denmark were diagnosed from 1985 to 1994 , the incidence was not calculated from that period.

Patients with hereditary rickets appeared several times in the registers throughout the study period due to continued attendance at outpatient clinics for treatment control. This allowed a calculation of the incidence of hereditary rickets throughout the entire study period. Since only one patient with hereditary rickets was non-Danish, the incidence was calculated among ethnic Danish children, and with the exception of one patient, all were diagnosed before the age of 3 years. The average yearly incidence was therefore calculated as the mean of the total number of ethnic Danish children diagnosed with hereditary rickets during the study period from 1985 to 2005 and born from 1982 to 2002 divided by the mean of the reported yearly total number of ethnic Danish children aged 0-0.9 years living in southern Denmark during 1982-2002. The prevalence of hereditary rickets among children 0-14.9 years of age on the 1st of January 2002 was calculated by dividing the total number of children with hereditary rickets on that date by the total number of children 0-14.9 years of age in southern Denmark at that date. We assumed that the children with hereditary rickets were diagnosed before the age of 4 years, and therefore children born before 2002 would be diagnosed by the end of the study period in 2005.

\section{Results}

A total of 214 medical records from children with a potential diagnosis of rickets were identified. The total population in the region was 1.3 million on the 1 st of January 2005, which equals $24 \%$ of the population in Denmark (5.4 million on the 1st of January 2005). The diagnosis of rickets was validated upon the previously defined diagnostic criteria of rickets, whereby 86 cases were excluded. Thus, 128 patients were included in the study. Of these, 112 patients had nutritional and 16 had hereditary rickets (Fig. 1).

Questionnaires were sent to the 480 GPs and pediatricians in the primary sector of southern Denmark and 360 (75\%) responded. Eleven children were referred from the primary health care sector to hospital evaluation in 2005 on suspicion of rickets. No children with rickets were treated exclusively in the primary sector.

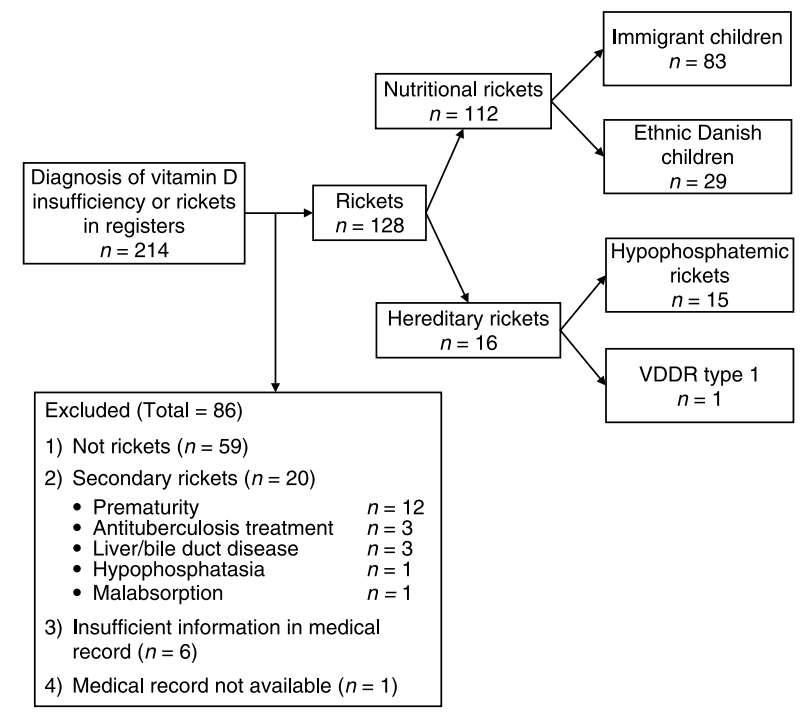

Figure 1 Flow diagram of patient inclusion.

\section{Nutritional rickets}

Of the 112 cases of nutritional rickets, 83 (74\%) occurred among immigrant children and $29(26 \%)$ among children of ethnic Danish origin. The age at diagnosis occurred in two incidence peaks among infants and young children aged 0.3-3.6 years and in older children and adolescents aged 5.1-14.8 years. Remarkably, ethnic Danish children were only diagnosed between age 5 and 24 months with 11 children diagnosed at age 5-11 months and 18 children at age 12-24 months. During the periods 1985-1994 and 1995-2005, the estimated average incidence of nutritional rickets in the total cohort was 1.7 and 2.9 per 100000 (0-14.9 years) per year respectively. Among ethnic Danish children, the estimated average incidences in the two periods were 5.0 and 2.0 per 100000 (0-2.9 years) respectively. The majority of the 83 immigrant children with nutritional rickets had parents of Middle Eastern $(n=50)$ or African $(n=22)$ origin. The highest incidences among children born in Denmark during the period 1995-2005 were found among children of Middle Eastern or African (85 and 59 per 100000 (0-14.9 years) per year respectively) origin. The average incidence during 1995-2005 among immigrant children born in Denmark was 60 per 100000 (0-14.9 years) per year and 100 per 100000 (0-2.9 years) per year (Table 1).

\section{Hereditary rickets}

A total of 16 cases presented with hereditary rickets during the study period. With the exception of one patient in whom the diagnosis was established at 9.4 
Table 1 Average yearly incidence of nutritional and hereditary rickets in southern Denmark.

\begin{tabular}{|c|c|c|c|c|c|}
\hline $\begin{array}{l}\text { Diagnosed } \\
\text { during }\end{array}$ & $\begin{array}{l}\text { Age group } \\
\text { (years) }\end{array}$ & $\begin{array}{l}\text { Regions } \\
\text { countries }\end{array}$ & $\begin{array}{c}\text { Average yearly } \\
\text { number of children } \\
\text { by ethnicity }^{\mathrm{a}}\end{array}$ & $\begin{array}{l}\text { Average yearly } \\
\text { number of cases }\end{array}$ & $\begin{array}{l}\text { Average incidence } \\
\text { (per } 100000 \text { per year) }\end{array}$ \\
\hline \multicolumn{6}{|c|}{ Nutritional rickets } \\
\hline \multirow[t]{3}{*}{ 1985-1994 } & $0-14.9$ & All children ${ }^{\mathrm{b}}$ & $197808^{c}$ & 3.4 & 1.7 \\
\hline & $0-2.9$ & All children ${ }^{b}$ & $38760^{\mathrm{C}}$ & 3.2 & 8.3 \\
\hline & $0-2.9$ & Ethnic Danish children & $37820^{c}$ & 1.9 & 5.0 \\
\hline \multirow[t]{9}{*}{ 1995-2005 } & $0-14.9$ & All children ${ }^{\mathrm{b}}$ & 246972 & 7.1 & 2.9 \\
\hline & $0-14.9$ & $\begin{array}{l}\text { Immigrant children born in } \\
\text { Denmark }\end{array}$ & 5003 & 3.0 & 60 \\
\hline & $0-14.9$ & $\begin{array}{l}\text { Middle East countries } \\
\text { Lebanon, Iraq, Pakistan }\end{array}$ & 2345 & 2.0 & 85 \\
\hline & $0-14.9$ & $\begin{array}{l}\text { African countries } \\
\text { Somalia, Eritrea, } \\
\text { Ethiopia }\end{array}$ & 922 & 0.5 & 59 \\
\hline & $0-14.9$ & $\begin{array}{l}\text { Asia } \\
\text { Sri Lanka }\end{array}$ & 993 & 0.2 & 18 \\
\hline & $0-14.9$ & $\begin{array}{l}\text { The Balkans } \\
\text { Bosnia }\end{array}$ & 743 & 0.3 & 37 \\
\hline & $0-2.9$ & All children ${ }^{\mathrm{b}}$ & 48327 & 2.8 & 5.8 \\
\hline & $0-2.9$ & Ethnic Danish children & 44699 & 0.9 & 2.0 \\
\hline & $0-2.9$ & $\begin{array}{l}\text { Immigrant children born in } \\
\text { Denmark }\end{array}$ & 1818 & 1.8 & 100 \\
\hline $\begin{array}{l}\text { Diagnosed } \\
\text { during }\end{array}$ & $\begin{array}{l}\text { Age group } \\
\text { (years) }\end{array}$ & $\begin{array}{l}\text { Type of hereditary } \\
\text { rickets }\end{array}$ & $\begin{array}{c}\text { Average yearly } \\
\text { number of children }\end{array}$ & $\begin{array}{l}\text { Average yearly } \\
\text { number of cases }\end{array}$ & $\begin{array}{l}\text { Average incidence } \\
\text { (per } 100000 \text { per year) }\end{array}$ \\
\hline \multicolumn{6}{|c|}{ Hereditary rickets, ethnic Danish children } \\
\hline \multirow[t]{3}{*}{ 1985-2005 } & $0-0.9$ & Hereditary rickets, overall & 14558 & 0.62 & 4.3 \\
\hline & $0-0.9$ & Hypophosphatemic rickets & 14558 & 0.57 & 3.9 \\
\hline & $0-0.9$ & VDRR type 1 & 14558 & 0.05 & 0.3 \\
\hline
\end{tabular}

${ }^{a}$ Estimated by computing a mean of the total number of children in the reported age group living in southern Denmark per year during the study period. Source: Statistics Denmark (http://www.statistikbanken.dk/ (accessed $20^{\text {th }}$ November 2008)).

${ }^{\mathrm{b}}$ All children: includes ethnic Danish children and immigrant children, regardless of birthplace.

${ }^{c}$ Exclusive children living in southern Jutland County during 1985-1991.

${ }^{d}$ Estimated by computing a mean of the total number of children aged 0-0.9 years and living in southern Denmark per year during 1982 to 2002 . Source: Statistics Denmark http://www.statistikbanken.dk/ (accessed $20^{\text {th }}$ November 2008)).

years of age, all patients with hereditary rickets were diagnosed before the age of 3 years. Overall, 15 patients had hypophosphatemic rickets and one had VDDR type 1. In ethnic Danish children, the estimated average incidence of hereditary rickets was 4.3 per 100000 (0-0.9 years) per year. The estimated average incidence of hypophosphatemic rickets and VDDR type 1 was 3.9 and 0.3 per $100000(0-0.9$ years) per year respectively (Table 1). The prevalence of hypophosphatemic rickets and VDDR type 1 was 4.8 per $100000(0-14.9$ years $)$ and 0.4 per $100000(0-14.9$ years $)$ on the 1 st of January 2002 respectively (Table 2). With the exception of one child, all children with hereditary rickets were of ethnic Danish origin.

\section{Discussion}

The average incidence of nutritional rickets among children aged 0-14.9 years and living in southern Denmark during the periods 1985-1994 and 19952005 was 1.7 and 2.9 per 100000 per year respectively. The incidence of rickets before 1995 is probably underestimated as outpatients were not included. However, our survey indicated that all children with rickets were referred to hospital treatment, thereby making the estimated incidences from 1995 to 2005 reliable. Ethnic Danish children were only diagnosed between age 5 and 24 months and the incidence in ethnic Danish children aged 0-2.9 years was reduced from 5.0 per 100000 during 1985-1994 to 2.0 per 100000 during 1995-2005. Despite this reduction in incidence, the incidence among ethnic Danish children aged 0-2.9 years was unexpectedly high. The incidence of nutritional rickets was considerably higher among immigrants born in Denmark than among ethnic Danes.

Table 2 Prevalence of hereditary rickets in children younger than 15 years, living in southern Denmark on the 1st of January 2002.

\begin{tabular}{lccc}
\hline $\begin{array}{l}\text { Type of hereditary } \\
\text { rickets }\end{array}$ & $\begin{array}{c}\text { Total } \\
\text { number } \\
\text { of children }\end{array}$ & $\begin{array}{c}\text { Total } \\
\text { number } \\
\text { of cases }\end{array}$ & $\begin{array}{c}\text { Prevalence } \\
\text { (per 100 000) }\end{array}$ \\
\hline $\begin{array}{l}\text { Hereditary rickets, } \\
\text { overall }\end{array}$ & 251234 & 13 & 5.2 \\
$\begin{array}{l}\text { Hypophosphatemic } \\
\text { rickets }\end{array}$ & 251234 & 12 & 4.8 \\
VDRR type 1 & 251234 & 1 & 0.4 \\
\hline
\end{tabular}


The reduction in incidence of nutritional rickets among ethnic Danish children coincides with the vitamin D recommendations launched in 1995 from The Danish National Board of Health. Prior to 1995, the recommendation for all children was vitamin D supplementation of $10 \mu \mathrm{g} /$ day from 14 days until 1 year of age, irrespective of ethnicity. In 1995, the period of recommendation of vitamin D supplementation among immigrant children was extended until 2 years of age. Ethnic Danish children were advised to continue the existing recommendation of vitamin D supplementation. This announcement has most likely contributed to an increased awareness among GPs and health visitors to ensure vitamin D supplementation both among immigrants and ethnic Danish children.

A previous Danish study of nutritional rickets among children admitted to three hospitals within the Copenhagen area from 1990 to 1999 found 40 cases of nutritional rickets, all occurring among immigrant children (Middle East $n=28$, Africa $n=10$, Yugoslavia $n=2$ ). Patients were identified upon diagnosis codes referring to rickets, traced in the hospital registers only. No incidence was calculated, but the authors observed 40 cases during a 10-year period in an area with approximately 1.6 million inhabitants (3). We identified 78 cases during an 11-year period in an area with 1.3 million inhabitants suggesting an incidence in southern Denmark of more than double that of the Copenhagen area. In 1995, 12\% of the inhabitants in Copenhagen were immigrants compared with $4 \%$ in southern Denmark (http://www.statistikbanken.dk/). Therefore, more cases of nutritional rickets would be expected in the Copenhagen area compared with southern Denmark, and in addition some cases to occur among ethnic Danish children. The register search in the study from Copenhagen did not include a search in DNPR, which might explain the fewer identified cases.

Our findings are in line with the findings of a recent study conducted among Canadian pediatricians. The overall annual incidence of nutritional rickets was 2.9 per 100000 (0-18 years) (4). In a study conducted in the West Midlands, UK, the incidence of nutritional rickets was 7.5 per 100000 per year among 0-5-yearold children $(n=24)(5)$. The highest incidence was seen in African children (95 per 100000$)$ followed by Asian children (38 per 100 000). The incidence among 0-5-year-old children of white ethnic origin was 0.4 per 100000 per year, but the calculation was based on only one case. In our study, the young patients only presented from age 0.8 to 2.7 years during the period 1995-2005. The incidence was 5.8 per 100000 (0-2.9 years) per year among children of all ethnicities and 2.0 per 100000 per year among ethnic Danish children. The incidences among all young children in the UK were higher, which might be attributable to the higher incidence among immigrants and a higher proportion of immigrants living in the West Midlands compared with southern Denmark.
Our study was larger than previous incidence studies; however, rickets is a rare disease and our estimates may therefore be uncertain. Our survey of GPs and pediatricians demonstrated that children with severe rickets are referred to hospital in Denmark. Mild cases, however, might have been treated in outpatient clinics and thereby escaped our attention. In addition, nutritional rickets in adolescence often presents with unspecific symptoms and may therefore be misclassified or not be diagnosed, thereby underestimating the incidence. The prevalence of nutritional rickets was not estimated because the duration of the disease was unknown. The diagnosis of nutritional rickets is very often delayed by several months and the data on when complete healing of rickets occurred was not always available in the medical records. In addition, a large seasonal variation in diagnosis of nutritional rickets occurs in Denmark (7). We presume that the identified cases of nutritional rickets were predominantly vitamin $\mathrm{D}$ deficiency rickets, but in children with no measurement of serum $25(\mathrm{OH}) \mathrm{D}$, calcium deficiency rickets cannot be excluded.

In our study, the majority of immigrant children with nutritional rickets had parents from the Middle East (predominantly Lebanon) and Africa (mainly Somalia). Due to religious beliefs, girls from these areas are often veiled. It is well established that the photochemical conversion of vitamin D in the skin by u.v. B rays is almost completely inhibited by clothing (14). Moreover, the children of African origin all came from countries where the native population has dark colored skin, which demands up to six times larger dose of u.v. B radiation to produce the same amounts of vitamin $\mathrm{D}$ as fair skin $(15,16)$. In Denmark, immigrant children were advised a daily vitamin $D$ supplementation of $10 \mu \mathrm{g}$ from 14 days until 2 years of age during the study period, but from 2005 the Danish National Board of Health has extended this recommendation to the entire childhood.

No photo conversion can take place in Denmark from October until March (15), which confines the vitamin D source to food supply or supplementation. Since the average intake from the food supply of vitamin D in the Danish population is low, in children $2 \mu \mathrm{g}$ /day and in adults $3.3 \mu \mathrm{g} /$ day (17), an adequate intake of vitamin D during summer months depends on sunlight exposure or vitamin D supplementation, and during winter months on vitamin D supplementation or possibly from foods enriched with vitamin D.

There are different possible approaches to improve the vitamin D status of children living in Denmark. A recommendation of increased sun exposure has no effect during winter months at this latitude (15) and during the summer months the possibility of increased risk of skin cancer due to increased sun exposure has to be considered. Since vitamin D is of limited availability in foods, it is not likely that the encouragement of pregnant and lactating mothers and of children to consume more fish, egg and meat will sufficiently 
increase their vitamin D status. A daily vitamin D supplement of $10 \mu \mathrm{g}$ is already advised during pregnancy, during the first year of life in ethnic Danish children, and throughout childhood in immigrant children. Since the majority of cases among ethnic Danish children were diagnosed after 12 months of age, we recommend an extension of the supplementation period until 2 years of age in ethnic Danish children. An increased awareness, especially among obstetricians, GPs and health visitors, of commitment to the advised daily vitamin D supplementation during pregnancy and in children is an important preventative step. In 2005, the Danish National Board of Health launched a nationwide campaign to increase the awareness of vitamin $\mathrm{D}$ deficiency and the need for a daily vitamin D supplement especially among immigrants living in Denmark, but compliance may be a major challenge. A possible approach towards elimination of rickets in Denmark may also be the introduction of food fortification with vitamin D taking ethnic variations in diet into account.

To our knowledge, our study is the first to provide the data on the incidence and prevalence of hereditary rickets. The only previously published incidence of hypophosphatemic rickets is a conservative estimate of $1: 20$ 25000 (6), corresponding to 4-5 per 100 000. However, no information about age group, nationality or time period over which it was calculated was defined, and we therefore suspect that this estimate is a prevalence. We calculated the incidence of hypophosphatemic rickets in ethnic Danish children to 3.9 per 100000 (0-0.9 years) per year and the prevalence of hypophosphatemic rickets to 4.8 per $100000(0-14.9$ years) on the 1st of January 2002, corresponding to 1:21000. The prevalence of VDDR type 1 was 0.4 per 100000 (0-14.9 years), but this estimate was based on only one case. The incidence of hereditary rickets in ethnic Danish children was 4.3 per 100000 (0-0.9 years) per year. All children with hereditary rickets are assumed to be referred to hospital and the observed incidence is therefore probably valid. Several authors have stated that hereditary rickets is now the most common cause of rickets in the western world (18-23). In our study, hereditary rickets was the most common cause of rickets among ethnic Danish children, but among all children aged less than 3 years and living in southern Denmark, nutritional rickets was still the most common cause of rickets.

In conclusion, nutritional rickets is rare and in Denmark occurring predominantly among immigrants. The incidence of nutritional rickets among ethnic Danish children (0-2.9 years) was, however, unexpectedly high but tended to decrease during the study period. A possible preventive approach might be extension of the supplementation period until 2 years of age in ethnic Danish children and/or introduction of food fortification with vitamin D. Finally, our study indicates that hereditary rickets is the most common cause of rickets in ethnic Danish children, but overall, nutritional rickets among children younger than 3 years of age, is still more common than hereditary rickets in southern Denmark.

\section{Declaration of interest}

There is no conflict of interest that could be perceived as prejudicing the impartiality of the research reported.

\section{Funding}

This work was funded by grants from A J Andersen og Hustrus Fond, the A P Moeller Foundation for the Advancement of Medical Science, Herta Christensens Fond, Institute of Clinical Research Odense University Hospital, Direktoer Jacob Madsen og Hustru Olga Madsens Fond, Karola Joergensens Forskningsfond, K A Rohde og Hustrus legat, and Simon Fougner Hartmanns Familiefond.

\section{References}

1 Berry JL, Davies M \& Mee AP. Vitamin D metabolism, rickets, and osteomalacia. Seminars in Musculoskeletal Radiology 20026 173-182.

2 Thacher TD, Fischer PR, Strand MA \& Pettifor JM. Nutritional rickets around the world: causes and future directions. Annals of Tropical Paediatrics 200626 1-16.

3 Pedersen P, Michaelsen KF \& Molgaard C. Children with nutritional rickets referred to hospitals in Copenhagen during a 10-year period. Acta Paediatrica 200392 87-90.

4 Ward LM, Gaboury I, Ladhani M \& Zlotkin S. Vitamin D-deficiency rickets among children in Canada. Canadian Medical Association Journal 2007177 161-166.

5 Callaghan AL, Moy RJ, Booth IW, Debelle G \& Shaw NJ. Incidence of symptomatic vitamin D deficiency. Archives of Disease in Childhood 200691 606-607.

6 Davies M \& Stanbury SW. The rheumatic manifestations of metabolic bone disease. Clinics in Rheumatic Diseases 19817 595-646.

7 Beck-Nielsen SS, Jensen TK, Gram J, Brixen K \& Brock-Jacobsen B. Nutritional rickets in Denmark: a retrospective review of children's medical records from 1985 to 2005. European Journal of Pediatrics, 2008 In Press, DOI: 10.1007/S00431-008-0864-1.

8 Lips P. Which circulating level of 25-hydroxyvitamin D is appropriate? Journal of Steroid Biochemistry and Molecular Biology 2004 89-90 611-614.

9 Shaw NJ. Vitamin D deficiency rickets. Endocrine Development 2003 6 93-104.

10 Drezner MK. Hypophosphatemic rickets. Endocrine Development 20036 126-155.

11 Kim CJ, Kaplan LE, Perwad F, Huong N, Sharma A, Choi Y, Miller W \& Portale A. Vitamin D 1 $\alpha$-hydroxylase gene mutations in patients with $1 \alpha$-hydroxylase deficiency. Journal of Clinical Endocrinology and Metabolism 200792 3177-3182.

12 Mughal Z. Rickets in childhood. Seminars in Musculoskeletal Radiology 20026 183-190.

13 Holick MF. Resurrection of vitamin D deficiency and rickets. Journal of Clinical Investigation 2006116 2062-2072.

14 Matsuoka LY, Wortsman J, Dannenberg MJ, Hollis BW, Lu Z \& Holick MF. Clothing prevents ultraviolet-B radiation-dependent photosynthesis of vitamin D3. Journal of Clinical Endocrinology and Metabolism 199275 1099-1103.

15 Webb AR. Who, what, where and when-influences on cutaneous vitamin D synthesis. Progress in Biophysics and Molecular Biology 200692 17-25.

16 Clemens TL, Adams JS, Henderson SL \& Holick MF. Increased skin pigment reduces the capacity of skin to synthesise vitamin D3. Lancet $1982174-76$. 
17 Lyhne N, Christensen T, Groth MV Fagt S, Biltoft-Jensen A, Hartkopp H, Hinsch H, Matthiessen J, Møller A, Saxholt E \& Trolle E. Sanholi Danskernes kostvaner 2000-2002. Silkeborg bogtryk, Danmarks Fødevareforskning. Afdeling for Ernæring, 2005.

18 Boukpessi T, Septier D, Bagga S, Garabedian M, Goldberg M \& Chaussain-Miller C. Dentin alteration of deciduous teeth in human hypophosphatemic rickets. Calcified Tissue International $2006 \mathbf{7 9}$ 294-300.

19 DiMeglio LA \& Econs MJ. Hypophosphatemic rickets. Reviews in Endocrine and Metabolic Disorders 20012 165-173.

20 Farrow EG, Davis SI, Ward LM \& White KE. The role of DMP1 in autosomal recessive hypophosphatemic rickets. Journal of Musculoskeletal and Neuronal Interactions 2007 310-312.
21 Garg RK \& Tandon N. Hypophosphatemic rickets: easy to diagnose, difficult to treat. Indian Journal of Pediatrics 199966 849-857.

22 Glorieux FH, Bordier PJ, Marie P, Delvin EE \& Travers R. Inadequate bone response to phosphate and vitamin D in familial hypophosphatemic rickets (FHR). Advances in Experimental Medicine and Biology $1978 \mathbf{1 0 3} 227-232$.

23 Hanna JD \& Chan JC. Renal hypophosphatemic rickets. Current Therapy in Endocrinology and Metabolism 19976 533-540.

Received 11 December 2008

Accepted 15 December 2008 